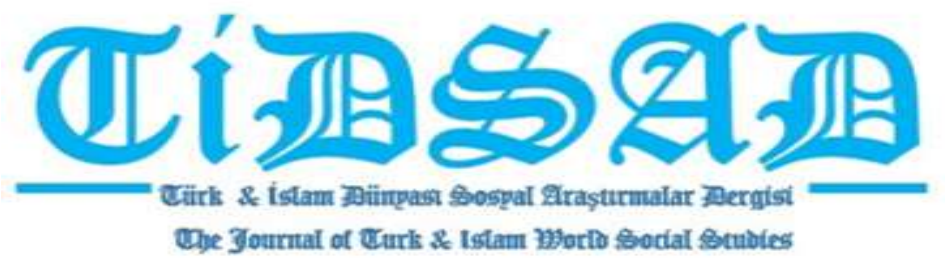

Yıl: 6, Sayı: 23, Aralık 2019, s. 181-196

Emir S.DEMİRCi

İstanbul Aydın Üniversitesi, Fen Bilimleri Enstitüsü Mimarlık Bölümü, emir_demirci@windowslive.com

Danışman: Prof. Dr. Zülküf GÜNELİ

\title{
YEŞIL ÇATILARIN SÜRDÜRÜLEBILIR KENT TASARIMINA OLAN ETKISI $^{1}$
}

Özet

Hava kirliliği ve küresel ısınmanın beraberinde getirdiği problemlere çözüm olarak alınacak birçok tedbirden yanlızca biri olan yeşil çatı uygulamaları yeterli bilincin olmaması ve yüksek ilk yapım maliyetinden ötürü nadiren tercih edilmektedir.Oysa plansız,düzensiz büyüyen her yanı betonlaşan şehirlerin değişen ve kirlenen havasını temizleyebilmek,rekreasyon alan ihtiyacını karşılayabilmek,tasarruf sağlayabilmek,şehrin estetik görüntüsünü değiştirebilmek,iklim değişikliğinin getirdiği felaketlere önlem almak adına yeşil alanlara daha çok ihtiyaç duymaktayız.Mevcut düzensiz yapılaşmanın yerine yeşil alanların gelmesi ütopik bir düşünce olduğundan ötürü yeşil çatı uygulaması burada bir önlem olarak daha çok öne çıkmaktadır.Yeşil çatı uygulamaları sürdürülebilir çevreye duyarlı yapılarda karşımıza çıkmaktadır.Yeşil çatılardan maksimum fayda elde edebilmek adına diğer sürdürülebilir prensibler ile birlikte uygulanması verimi arttıracaktır.Her geçen gün daha katı tedbirler almak zorundayız.Ekolojik dengenin sağlanması adına yeşil alanlardaki bitkilelerin çeşitliliği büyük önem taşımaktadır doğal yeşil alanların aksine yeşil çatılar çok daha fazla türün bir arada bulunabilmesini sağladığından dolayı aynı metrekaredeki bir yeşil alana göre çok daha verimlilik sağlamaktadır.

Anahtar Kelimeler: Yeşil çatı,yeşil alan,sürdürülebilirlik,ekolojik denge

\footnotetext{
${ }^{1}$ Bu makale İstanbul Aydın Üniversitesi Prof. Dr. Zülküf GÜNELİ' in danışmanlığında hazırlanan "Hava Kirliliği ve Küresel Isınmayı Önlemede Yeşil Çatıların Etkileri Üzerine Kritik Bir Değerlendirme” başlıklı yüksek lisans tezinin bir bölümünden türetilmiştir.
} 


\title{
THE IMPACT OF GREEN ROOFS ON SUSTAINABLE URBAN DESIGN
}

\begin{abstract}
Green roofs, one of the many precautions that can be taken in order to inhibit some of the problems occured by air pollution and global warming are rarely prefered because of their high inital construction cost and also insufficient knowledge of the users.

As a matter of fact we need green spaces now more than ever to have a clear air, to provide for the need of recreational areas, to save on, to prevent problems made by global warming and also to change the aesthetic view of our unmethodical growing cities.

Replacing the current unmethodical structures with green spaces is more like a utopia, therefore, green roofs play a better countermeasure role.

We can come across green roof applications in sustainable environment structures.

Having sustainable principles and green roofs work together would maximize the benefits.

Strict measures need to be taken each day.

Having variety of plants plays a huge role in providing an ecological balance.

Green roofs allow a lot of different species to live together which increases the benefits compared to natural green spaces over a square meter.
\end{abstract}

Keywords: Green Roof,Green Place,Sustainability

\section{GIRIŞ}

Büyük kentlerin hızlı ve düzensiz gelişimi sonucunda yaşam alanları, büyük ölçüde beton ve asfaltla kaplanmıştır. Kent içinde bulunması gereken yeşil alanlar, yerleşim fonksiyonlarının ve iş yerlerinin yoğun baskısına dayanamayarak, yerlerini betonarme yapılara terk etmektedir. Kentsel çevre sorunları birçok kentin temel sorundur. Bu duruma karşı en etkili çözüm yollarından biri, yitirilmiş olan bitki alanlarının, kendilerini yok eden yapıların üzerinde yeniden tasarlanması ve uygulanması, yani çatıların yeşillendirilmesidir.

"Yeşil çatılar bugün çatı bahçelerinin estetik amaçlarının yanı sıra, ekolojik amaçlar için de kullanılan ve "ekolojik çatılar" ya da "yeşil çatılar" olarak adlandırılan tiplerdir. Yeşil çatı kavramı, binaların yaşayan çevreye uyum sağlaması için kullanılan bir kavramdır. Bu yeni ekolojik çatı bahçeleri, binaların yapısal sistemini çok az değiştirerek ya da hiç değiştirmeden, çok fazla sulama ya da bakım gerektirmeden, kentlerdeki çatıları yaşayan bir bitki örtüsüyle kaplamak olarak tanımlanabilir. Bu tip çatı bahçelerinin yapımı oldukça kolaydır ve çevreye önemli faydaları bulunmaktadır" (Worden, 2004). Ticari, endüstriyel ve konutlar gibi çatı alan yüzdesi yüksek olan binaların toprak kullanım oranlarını ve akış hacimlerini düşürmede en etkin yöntem yeşil çatılardır.

Yeşil çatılar kent ve yapı görseline sağladıkları olumlu etki dışında sahip oldukları katmanlar yapıya ses ve 1sı izolasyonu sağlar,yangın dayanımını arttırır,enerjinin daha etkin mümkün hale getirir,havadaki toz partiküllerinin yutularak havanın temizlenmesini sağlar,yapının ömrünü uzatır yani kısaca yeşil çatılar ekonomik,sosyal ve ekolojik bir çok avantajı beraberinde getirir. (Koç ve Gültekin 2010). 


\subsection{Araştırmanın Amacı ve Kapsamı}

Her geçen gün artan nüfusun ve bu nüfusun ihtiyaçlarını karşılamak için gerekli olan enerji ihtiyacının büyük çoğunluğu fosil yakıtlardan elde edilmektedir.Ve bu yakıtların kullanımı aynı anda hem havayı hem toprağı kısacası tüm dünyadaki ekolojik dengeyi tehdit etmektedir.Ekolojik dengenin bozulmasının en büyük etkisini değişen iklim olaylarından anlamaktayız.Kalabalıklaşan şehirler tüm ekolojiyi tahrib etmekte ve telafisi mümkün olmayan sonuçlara sebep olmaktadır.

Bunca kirliliğin en büyük nedeni ise insanın en temel ihtiyaçlarından biri olan barınma ihtiyacının sürdürülebilir olmaktan çok uzak olan yapım ve kullanım şekilleridir.Sürdürülebilir olmanın amacı sonraki kuşaklardan ödünç aldığımız bu dünyayı daha yaşanılabilir, doğayla daha barışık ve daha çevre bilincine sahip olmaktır.Araştırma kapsamında yeşil çatıların günümüz metropollerinde olan uygun örnekleri üzerinden olumlu ve olumsuz tüm etkileri irdelenmiştir

\section{Sürdürülebilirlik Kavramı ve Yeşil Çatılar}

Her ne kadar günümüzde değişimi artık gözle görülebilir hale gelsede dünyamız ekosistemi ile barış içerisinde yaşayabilmek mümkündür. Çevre tüm canlıların etkileşim içinde olduğu biyolojik,kültürel ve fiziksel ortamdır.Doğal ve yapay olmak üzere 2'ye ayrılır.

Doğal çevrenin diğer adı ekosistemdir.Bu sistemde tüm canlılar etkileşim içindedir.Herhangi bir değişim tüm ekosistemde değişikliğe neden olur.

Sistem kendi içerisinde uyumlu bir şekilde işler tüm bu canlı ve cansız varlıklar arasında dengeli bir ilişki bulunur buna "Ekolojik Denge" denir.( Erengezgin,2001).Bir takım önlemler 1şı̆̆ 1 altında ekosistemle barışık yapılar tasarlamak mümkündür. İşte bu durumda yapıların bulunduğu çevreyle ne denli uyum içinde olduğunu ne denli zararlı ne denli zararsız olduğunu denetlenmesi yani sürdürülebilirliklerinin belirlenmesi gerekmektedir.Sürdürülebilir yapılar temelinden çatısına,yapımından kullanımına tüm aşaması denetlenen ve uygunluğu belirlenen yapılardır.Yeşil çatılar ise sürdürülebilir tedbirlerden yanlızca biri fakat en önemlileri arasında yer almaktadır.

\subsection{Sürdürülebilirlik Kavramı Ve Önemi}

"Sürdürülebilirlik daimi olabilme yeteneğini korumak demektir.Sürdürülebiliklik 1987 yılı Birleşmiş Millet Çevre ve Kalkınma Komisyonunda ele alınmıştır. Sürdürülebilirliğin temelinde gelecek nesillerde dikkate alınmış,çevreyle daha barışık,daha ekolojik çözümler bulunması amaçlanmıştır.Sürdürülebilir mimarlık genel anlamıyla insanların konuttaki konforlarından ve diğer ihtiyaçlarından ödün vermeden enerjiyi,suyu,alanı ve malzemeyi etkin kullanmak demektir.Bu sistem günümüz gereksinimlerini karşılarken gelecek kuşakları tehlikeye sokmayan bir uygulamadır.Sürdürülebilir mimarlık yanlızca kaynaklardan maksimum fayda sağlanmasını amaçlamaz aynı zamanda atıkların geri dönüşümünü yapıların kent içerisindeki konumunu ,yapıların alt yapı sistemlerine olan etkisinide kapsar.Sürdürülebilirlikte en önemli madde çevreye verilen zararın minimuma indirilmesidir”.(Uysal,2002)

Sürdürülebilirlik kavramı sahip olduğumuz kaynakların hızla ve geridönüştürülemeyecek şekilde kullanılmasından ötürü çok önemlidir.Sürdürülebilirlik kavramının önemini şu 3 başlık 
altında özetleyebiliriz.

*İnsan sağlı̆̆ı,şehirleşme,kontrolsüz nüfus artışı ve akabinde artan hava kirliliği nedeniyle daha yaşanılabilir bir çevre açısından,

*Doğal kaynakların daha verimli tüketilmesi ,

*Enerjide dışa bağımlılığı azaltmak ve tüm dışa olan ekonomik bağımlılıktan kurtulmak için.

\subsection{Sürdürülebilir Yapı Sertifikaları (BREEAM,LEED)}

Yapıların yapım malzemelerinin ne derece sürdürülebilir olduğunu belirleyen ve buna göre yapıları derecelendiren kuruluşlar bulunmaktadır.Bu kuruluşların önde gelenleri İngiliteredeki BREEAM ve Amerikadaki LEED kuruluşlarıdır.Bunların yanında Kanadada kurulmuş olan SBTool Avusturalyadaki yeşil bina konseyi tarafindan oluşturulan Green Star ,Japonyadaki CASBEE de bulunmaktadır.Çok yaygın olarak bilinmesede diğer kuruluşlar Ecoprofile(Norveç),PromisE(Finlandiya),BEES,Green Mark For Buildings (Singapur).Çeşitli ülkelerde genellikle o ülkeye özgü sürdürülebilirlik standartları üzerine farklı sürdürülebilir sertifikasyon sistemleri bulunmaktadır.

$\mathrm{Bu}$ sertifikasyon sistemleri genel olarak yapıyı,yapı malzemelerini ve yapının çevreyle olan etkileşimi üzerine puanlama yapmaktadır.(Burçak,2014)

*BREEAM

İngiltere Yapı Araştırma kurumu tarafından hazırlanan ve bu sertifikasyon sistemi 1990 yılında kullanıma geçmiştir ve ölçütlere dayalı olarak değerlendirme yapan ilk sertifikasyon sistemdir.BREEAM açılımı "Yap1 Araştırma Kurumu Çevresel Değerlendirme Metodu"dur.BREEAM yeni yapıları inceler.

Ofisler,aileler için konutlar,eğitim kurumları,alışveriş merkezleri,sağlık merkezleri,sanayi alanları vb yerlerde çalışma yapmaktadır.Tüm bu yapıları oldukça geniş bir çerçevede inceler ve performansına göre değerlendirir.BREEAM aynı zamanda İngiltere dışındaki ülkeler içinde bir değerlendirme sistemi hazırlamıştır.Bu sistem aynı zamanda körfez ülkeleri tüm Avrupa ve ülkemizi de kapsar.İstendiği takdirde yapıya özgü değerlendirme ölçütü olan BREEAM Bespoke de hazırlanmaktadır.BREEAM'e göre bir yapının tüm kriterlerde ki puanların en az \% 30'unu toplaması gerekmektedir.BREEAM'in değerlendirmesine göre Pass,Good,Very Good,Excellent ve Outstanding olarak derecelendirilir. (Burçak,2014)

*LEED

Amerikan Yeşil Bina Konseyi (United States Green Building Council - USGBC) tarafından ilk defa 1998'de binaları sertifikalandırmaya başlayan LEED (Leadership in Energy and Environmental Design) değerlendirme sistemi inşaat sektörünün sürdürülebilirlik konusunda kendisini geliştirmesi düşüncesiyle ortaya çıkmıştır. Bunlar arsanın sürdürülebilir olup olmama durumu,yapının su etkinlik durumu,yapının enerjiye olan ihtiyacı ve atmosfere etkisi,yapıda kullanılan malzeme ve kaynakların ne derece sürdürülebilir olduğu ,iç mekan kalitesi ve tasarımsal yenilikler olarak sıralayabiliriz.

Yapının değerlendirmeye tabi tutulabilmesi için ön koşulları sağlaması 
gerekmektedir.Bu koşullar tasarım ve yapım olmak üzere 2 aşamalıdır ve bu aşamalar internet ortamından sisteme yüklenerek ön değerlendirmeye alınır.Leed yapıları gösterdiği performansa göre Certified,Silver,Gold ve Platinium olarak derecelendirir. (Burçak,2014)

\section{Yeşil Çatıların Tasarımsal Özellikleri Ve Türleri}

\subsection{Yeşil Çatı ve Yeşil Bina Kavramı}

Çatı yapıyı rüzgar,kar,yağmur vb gibi dış etmenlere karşı koruyan bir yapı elemanıdır.Çatılar üzerinde bulunduğu yapıyla bir bütün oluşturduğundan aynı zamanda estetik bir görünümede sahip olmalıdır. Çatılar çeşitli malzemeler kullanılarak inşa edilebilir bunlar beton,ahşap ve çelik olmak üzere 3 çeşit olarak sıralayabiliriz.Standart çatıları yanı sıra sürdürülebilir yapı başlı̆̆ altında değerlendirebileceğimiz "yeşil çatılar"da bir diğer çatı türüdür.Yeşil çatılar aynı zamanda ekolojik çatı yada kahverengi çatı olarak da telaffuz edilmektedir.

Yeşil çatılar, ilave ağırlığa dayanma gücü olan; su, su buharı ve kökler yoluyla meydana gelen penetrasyona karşı çatıyı koruyan; az yağış sürelerini artırmak için bitkilerin yeterli nemi tutmasını sağlayan fakat gerektiğinde fazla nemi dışarıya atabilen; bitkileri desteklemek için toprak benzeri ayrışan madde sağlayan; iklim bölgesi için uygun, sürdürülebilir bir bitki örtüsünün devamlılığını sağlayan; bina, insanlar ve çevre için birtakım hidrolik, atmosferik, termal ve sosyal fayda sağlayan; alttaki bileşenleri ultraviyole ve termal bozunumdan koruyan sistemlerin bütünüdür. Ayrıca yeşil çatı tanımlarını aşağıdaki şekilde çoğaltabiliriz.(Olgun,2014)

Yeşil çatıların tasarımsal özelliklerini etkileyen çeşitli faktörler bulunmaktadır.Yeşil çatının uygulanacağı yapının taşıma kapasitesi,o bölgeye ait iklim şartları,yeşil çatının o bölge üzerindeki etkisi ve tabiki kullanıcı istekleri yeşil çatı tasarımını değiştiren faktörler olarak sayabiliriz.Bu sayılan şartlara göre yeşil çatıları ekstansif (seyrek bitkili) ve intansif (yoğun bitkili) olmak üzere iki başlık altında inceleyebiliriz.Nadiren de olsa her semi-ekstansif(yarı seyrek bitkili) uygulamalı çatılarda yapılmaktadır.

Avrupa'da yapılan bir araştırmaya göre insanların bir çoğu vakitlerinin çok büyük bir kısmını bina içerisinde geçirmektedir.Bu nedenledir ki yaşadığımız yapıların bizimle ve çevreyle olan etkileşimleri iyi değerlendirilmeli malzeme seçimi ve tasarımna özen gösterilmelidir.

Ne yazık ki özellikle ülkemiz şehirleri yapıların çevreyle ve insanla olan etkileşimi üzerine değil rant odaklı geliştiğinden yeşil bina ve yeşil çatılar rantsal büyümenin içerisinde alınabilecek çok önemli bir tedbirdir.Yeşil bina ve buna bağlı olarak yeşil çatılı yapı kavramı yapıların insan sağlığı üzerinde olan etkisini azaltmak ve çevreye daha az zarar vermek düşüncesi sonucunda ortaya çıkmıştır.

Herhangi bir sürdürülebilir tedbire sahip olmayan yap1 ve şehirlerin ekolojik sisteme olan etkisini artan 1Sı adaları ve değişen iklim şartlarıyla dışarıdanda çok kolay bir şekilde gözlemleyebilmekteyiz. Yeşil Bina ve Yeşil Çatılı Binaların Temel Birkaç Hedefi; 
*Çevreyle daha bütünleşik ve insan sağlığı açısından daha uygun yapılar..

*Yapının yanlızca yapım sonrası kullanım giderlerini değil yapının arsa üzerinden konumlandırılmasından,malzemeden sermayeye kadar tüm kalemlerin en verimli şekilde kullanımını hedefler..

*Fosil yakıt kullanılarak üretilen enerji kaynakları kullanmaktansa geri dönüştürülebilir enerji kaynaklarını kullanmayı amaçlar..

*Ve tabi ki sera gazının neredeyse \%50'sinin oluşmasına neden olan yapının inşa ve kullanım sırasında ortaya çıkan bu zararlı gazı minimuma indirmek..

*Atık maddelerin azaltılmasına atıkların yönetiminden depolanmasına ve geri dönüşümüne kadar firsat vermesi ve geri dönüştürülmüş malzeme kullanılması

*Yap1 iç hava kalitesi oranın sürekli en optimum seviyede kalmasının sağlanması maksimum oranda doğal aydınlatmadan faydalanılmasının sağlanması

\subsection{Ekstansif (Seyrek Bitkili) Çatılar}

Seyrek yeşillikli çatılar dünya üzerinde uygulanmış olan örnekleri göz önüne alındığında 10-15 cm toprak derinliğine sahip,intansif çatılara göre daha ucuz,yapıya getirdiği yük açısından daha hafif $(50-200 \mathrm{~kg} / \mathrm{m} 2$ suya doymuş ağırlığ $)$,ekstra bir sulama ve drenaj sistemi gerektirmeden varlığını devam ettirebilen,bakım gideri neredeyse 0 sayılabilecek çatı türüne denir.

Ekstansif çatıların bu özellikleri aynı zamanda istensif çatılar göz önüne alındığında bir avantaj olarak da sayllabilmektedir.

Ekstansif çatıların kurulacağı yapı yüzeyinin doğal drene edilebilmesi adına \%1,5-\%2 oranında eğime sahip olması gerekmektedir. Ekstensif yeşil çatılar, hafif yüklü sistemler olduğu için çatıda herhangi bir güçlendirme işlemi gerektirmemektedirler. Büyük alanlar için tercih edilebilecek sistemlerdir. Eğimli çatılara uygulanabilir olmaları da kullanım alanlarının yaygınlaşmasında etkilidir. Ekstensif yeşil çatılar sık sulama gerektirmeyen dolayısıyla drenaj sistemine de pek ihtiyaç duyulmayan çatılardır. Bitki örtüsü doğal haliyle kendiliğinden büyüyebilen bitkilerden oluşmaktadır. Ancak bu durum bitki seçiminde sınırlamalara neden olmaktadir.

Ayrıca sosyal kullanım alanı olarak uygulamaları olmaması da dezavantajları arasındadır. "Ağaçların üst kısımlarına gelen güneş ışınlarının emiliminde; radyasyonun çoğu buharlaşmaya bağlı soğumayla birlikte gizil 1sı akısına dönüşmektedir, böylece toprak yüzeyini ısıtacak güneş radyasyonunun geçişi engellenmekte ve bu şekilde yüzeye yakın bölgelerde hissedilir 1s1 düşmektedir. Ancak, çayır alanlarının aynı koruyuculuğu yaptığı söylenememektedir. $\mathrm{Bu}$ alanlarda gündüz belirgin 1sınmanın yanı sıra gece gündüz arasındaki sıcaklık farklarını arttıran gece soğumaları da meydana gelmektedir.

$\mathrm{Bu}$ noktada şu temel farklılık çok iyi ayırt edilmelidir, çim veya otsu bitkilerin etkisi hiçbir zaman odunsu bitkiler kadar etkin olamamaktadır. 


\section{3 İntansif (Yoğun Bitkili) Çatılar}

"Gerçek bir yeşil alan gibi sosyal kullanım alanı olarak kullanılabilen sahip olduğu altyapı ve toprak katmanı dolayısıyla neredeyse her türlü bitkinin kullanıldığı yeşil çatı türüne intansif çatı denir.Genel karakteristiği 15 ile $150 \mathrm{~cm}$ arası derinlikteki toprak tabakasına sahip olan bu yeşil çatılar,taşıyıcı sistem üzerine minimum 290kg yük getirdiği kabul edilir.Doğal yeşil alanlar gibi kullanılabildiği için ve hatta yapı üzerinde bulunduğu için yapımından bakımına ve onarım masraflarına kadar bir çok iş kalemi yüksek maliyetlidir.Yoğun bir tabakaya sahip olmasından ötürü uygulandığ1 yapılarda yüksek 1sı dolayısıyla enerji tasarrufu sağlamaktadır.Ayrıca yağmur suyunu tutması sayesinde yapının belirli yerlerinde bu suyun kullanım imkanı vardır”.(Erkul,2012)

İntensif çatı yeşillendirmesi, insanların çatıyı geleneksel bir bahçe gibi kullandığı eski tür bahçe çatılara benzer. Bitkilere, aynı yeryüzündeki bahçeler gibi kişisel bazda bakım yapılır. Basit intansif yeşil çatılar, yine de düzenli bakım gerektiren çimenlerle ve yer örtücü küçük bitkilerle kaplıdır, fakat daha ince substratları vardır ve bu yüzden kurulumu daha az maliyet gerektirir.

\subsection{Yeşil Çatıların İşlev ve Faydaları}

Yeşil çatılar, bina çatı yüzeyi üzerine monte edilen katmanlar ve bitki örtüsünden oluşan, doğal yoldan su muhafaza etme özelliklerinin yanı sıra, tozun kalkmasını ve yap1 içerisine 1sı geçişlerini ya da 1sı kaçaklarını ciddi oranda azaltabilme özelliğine sahip yapılardır. Ayrıca su tutma özelliği ile altyapı sistemlerinin yükünü de azaltmaya yardımcı olmaktadır. Yeşil çatı sistemleri güzel görüntü dışında ekolojik katk1, su yönetimine katkı, enerji kullanımına katkı gibi özellikleri nedeniyle yaygınlaşma yolunda ilerlemektedir.

Yeşil çatı dizaynında katman seçimi çatının performansını etkileyen kritik bir seçimdir. Katmanlar çatının intensif ya da ekstensif olmasına göre boyut, tür, şekil gibi özelliklerinde değişiklik gösterebilir. Yeşil çatılarda kullanılan katmanlar ise detaylı şekilde şekil 3.9 gösterilmiştir.

*Yeşil çatıların sahip olduğu katmanlar genel olarak şu şekilde sıralayabiliriz.

*Yeşil çatı türüne göre ağırlığı destekleyen yapı strüktürü

*Yapıyı yeşil alanın oluşturduğu nem,rutubet ve her türlü sudan gelebilecek zararlara karşı su yalıtımı, buhar önleyici katman

*Bitkinin ihtiyacı olan suyu depolomaya yarayan gözenekli katman

*Ince toprak nedeniyle gözenekli olan yapının tıkanmasını önleyen geosentetik katman

*Seçilen çatı türüne göre yetiştirilecek olan bitkiye uygun bir toprak tabaka

* Bu tabaka sistemine en basite indirmemiz gerekirse temel bileşenler olarak çatı strüktürü,su,buhar,nem,kök muhafaza yalıtımı,yeşil çatı türüne göre drenaj sistemi ve toprak katmanından oluşmaktadır.

"GREEN ROOF FOR HEALTY CITIES” kuruluşunun (Sağlıklı kentler için Yeşil Çatılar) yaptığı araştırmaya göre özellikle büyük kentlerin yüzey alanlarının $\% 75$ geçirimsiz yani toprak ile bağlantısı kesilmiş olan alanlardan oluşmaktadır.Hızla kentleşme yağan yağmurun toprak tarafından emilecek alanların yok olmasına neden olmaktadır.Aynı zamanda yoğun yerleşim 
bölgelerinde taşıtların neden olduğu zararlı gazları ve tozları filtreleyecek yeşil alanlar kentleşmeyle beraber azaldığı hatta yok edildiği için yeşil çatıların sürdürülebilir kent tasarımı açısından önemli bir işleve sahip olduğu apaçı ortadadır.Ülkemiz yapı sektörünün bir parçası olarak uygulanan yeşil çatılar yurtdışında bambaşka bir uzmanlık haline gelmiştir.(Uçurum,2007)

$\mathrm{Bu}$ tip çatıların tercih edildiği yapılarda verimliliği arttırmak ve doğaya verilen zararı azaltabilmek adına yerinden kazılan toprak çatıda kullanılmaktadır.Bu sayede ihtiyaç duyulan toprağın taşınması gibi bir maliyetten tasarruf edilmesi mümkün hale gelmektedir.

\subsection{1 Çevresel ve Ekolojik Faydaları}

\section{* Gürültü ve Ses Yalıtımına Etkileri}

Yoğun kent yaşamının neden olduğu gürültü sinir bozucu olmaktan öte birtakım sağlık problemlerinide beraberinde getirmektedir.Sürekli maruz kalınan gürültü psikolojik problemlere, işitme kaybına ve uyku bozukluğuna neden olduğu bilinmektedir.

Yeşil çatılar standart çatılara nazaran gürültünün yapı içerisine girmesine engel olur.Yeşil alanların azlığı ve sert yüzeyler gürültünün sürekli olarak yansımasına neden olur.3 ile $30 \mathrm{hz}$ aras1 alçak frekanslar toprak tarafından engellenirken,30-300 hz arası frekanslar ise bitki örtüsü tarafından engellenir.Frankfurt Havaalanın'da bulunan $10 \mathrm{~cm}$ derinliğindeki yeşil çatı örtüsünün gürültüyü $5 \mathrm{db}$ azaltığı ölçülmüştür. (Koç,2010).

Binaların ve kaldırımların sert yüzeyleri, sesi emmekten çok yansıtmaya meyillidirler. Bu yüzden, yeşil çatı bitkileri ve substratları, bina içlerindeki ses geçişlerini azaltarak emerler.

Daha derin substratlar sı̆̆ substratlardan daha fazla sesi emerler; bu yüzden intansif çat1 sistemleri, gürültü kirliliğini azaltmada daha başarılıdır. Buna rağmen $15 \mathrm{~cm}$ kadar sı̆̆ bir substrat, 40 desibel'e kadar sesi azaltabilir.

\section{* Su ve Atık Su Kullanımına Olan Etkileri}

Büyüyen kentlerle birlikte kaybolan yeşil alanların ortaya çıkardığı problemlerden bir diğeride toprak zeminin kaybolmasından ötürü yağan yağmurun yanlızca altyap1 sistemiyle drene edilmeye çalışması sonucu çoğu zaman altyapı problemleriyle karşılaşılmaktadır.

Yağışı drene etmeye yetmeyen altyapı sistemi tıkanmakta taşmakta ve zarara neden olmaktadır.Yeşil çatılar ise öncelikle suyun akış hızını yavaşlatarak ve yağışın çok daha geniş bir alanda emilimini sağlayarak altyapı üzerindeki yükü azaltmaktadır.

Yapılan gözlem ve araştırmalar göstermektedir ki yağış miktarı ne kadar çok olursa tutulan yağış miktarı o kadar az ne kadar az yağış olursa o denli çok miktarda yağış tutulmaktadır.25 mm'den düşük yağışlarda yağışın \%88'i tutulurken, orta ölçekli yağışlarda (25-76 mm) \%54'ten fazlası tutulduğu, büyük ölçekli yağışlarda ise (76 mm'den büyük) \%48 oranında yağışın tutulduğu görülmüştür.

Küçük ölçekli yağışlarda yeşil çatıdaki akışın geleneksel çatıya oranla daha az olduğunu ancak büyük ölçekli yağışlarda bu farkın azaldığını belirtmiş̧lerdir .10 mm'den küçük yağışların tamamının yeşil çatıda tutunabildiği ve akışı yaklaşık $10 \mathrm{dk}$ kadar geciktirdiği Simmons vd. tarafından 2008 yılında yapılan çalışmada gözlenmiştir. Yeşil çatılar bitki örtüsünde yağmur 
suyunu tutarak drenaj yoğunluğunu azaltmaya yardımc1 olur. "20-40 cm arası intensif bitkilendirilmiş bir çatı 10-15 cm yüksekliğinde su tutma kapasitesine sahiptir. Genel olarak kente düşen yağmur suyunun \%10-15'inin yeşil çatılarda tutulması mümkündür. $10 \mathrm{~cm}$ toprak kalınlığ 1 üzerine düşen yağmurun \%50'sini, $20 \mathrm{~cm}$ toprak ise \%60'ını tutabilmektedir. Bu oran $50 \mathrm{~cm}$ toprak kalınlığında \%90'a ulaşmaktadır”(Berdtsson,2012)

Yeşil çatı sistemleri aynı zamanda yapılarda kullanılan gri suyun (duş,küvet,lavabo) tekrar kullanılabilmesini sağlamaktadır.Diğer arıtma sistemlerine nazaran daha kısa sürede ve daha az maliyetle arındırılan gri su yapının tuvalet sifonlarında,araç yıkama gibi alanlarında tekrar kullanilabilir.

\subsubsection{Ekonomik Faydaları}

Ülkemizde toplam elektrik tüketiminin yaklaşık \%43’ü binalarda kullanılmaktadır. Enerji tüketiminde ilk sırada sanayiler olup ikinci sırayı binalar almaktadır. Binalarda tüketilen enerjinin \%65'i isıtma-soğutma, sicak su ve havalandırma sistemlerinde, \%20'si aydınlatmada, \%15'i beyaz eşya ve elektronik eşyalarda kullanılmaktadır. Isınma amaçlı kömür kullanımı ülkemizde 14 milyon ton/yıl civarındadır. Bu amaçla en yüksek tüketim son yıllarda doğalgazdan olup,güneş enerjisi, jeotermal gibi yenilenebilir enerjinin tüketimi de yaygınlaşmaktadır (Koca,2017).

Standart çatılarda taş, asfalt ve beton yüzeylerin gün boyunca güneşten gelen 1sıyı emerek gece de yaymasından dolayı geceleri hava sıcaklığının normalden daha üst seviyelere çıktığı görülmektedir. Bunun sonucu "kent 1s1 adaları" meydana gelmektedir.

Yeşil çatı sistemlerindeki bitki örtüsü, yapıda doğal havalandırma sağlayarak yaptığı gölge etkisiyle havanın soğumasına yardım eder ve yapının daha rahat nefes almasına olanak sağlar. Yeşil çatılardaki bitki örtüsü sağladığı bu gölge etkisiyle 1sı adalarının oluşumunun önüne geçmektedir. Ayrıca mevcut toprak tabakası da yapıda yalıtımı sağlamaktadır.

$\mathrm{Bu}$ durum yapıların 1sıtma gereksinimlerini ve 1sı kayıplarını $\% 50$ oranında azaltabilir .

Sonuçlar çeşitli olsa da, yeşil çatıların çatının altındaki zeminde soğutma için gereken enerjiyi \%50 oranında azaltabileceğini gösteren çalışmalar mevcuttur Yeşil çatı, 1sının çatıdan gitmesini engeller ve yaz boyunca gölgeleme ve terleme yoluyla binayı serin tutar.

Frankfurt, Almanya'daki Possman Elma Suyu Soğutma ve Depolama Tesisi, donanım maliyetinin yanında 1sıtma ve soğutma maliyetinde de tasarruf sağlayarak yeşil çatı sistemine 23 yıllık bir sermaye sağladığı bilinmektedir. Yeşil çatı sistemlerinden sonra, ek soğutma kuleleri gereksiz hale geldiği belirtilmiştir.(Olgun,2014)

İtalya'nın Vicenzo Hastanesi tarafından kurulan yeşil çatının termal performansı 2005 yılında Lazzarin tarafından incelenmiş ve analiz edilmiştir. Kuru dönemlerde yeşil çatı yalıtımının geleneksel çatıya kıyasla alttaki odaya giren 1sıda yaklaşık \%60 oranında tasarruf yaptığı gözlenmiştir .

Yeşil çatılar aynı zamanda bir hobi bahçesi olarak değerlendirildiğinde günlük bazda ihtiyacımız olabilecek sebze ve meyvelerin üretebilme firsatını bize sunmaktadır.Örneklerde de 
bahsedildiği üzere Vancouver Kongre Merkez binası çatısında yer alan 400 bin tür bitki ve bal arısı kolonisi ile kongre merkezinin mutfağında kullanılacak olan bal elde edilmektedir.Çatı bitkilendirilmesinin boyutuna bağlı olarak yeşil çatılarda üretilen sebze ve meyveler yerel işletmelerde satılabilmektedirler.

\subsubsection{Sosyal Faydaları}

Her yeşil çatı kendi ekosisteminide beraberinde getirir.Yeşil çatılar ekolojik çeşitlilik ve doğal yaşamı korumaya yardımcı olur,kentsel çevre içerisinde yaşam alanı oluştururlar.Yeşil çatılar havayı seyrelttiklerinden ötürü doğal ortam etkisinin oluşmasınıda sağlarlar.

Yeşil çatılar rekreasyon alanı olarakta kullanılabilme özelliğine sahiptir.Yeşil çatıların yapımı ile birlikte turizm,eğitim,sağlı ve ofis binalarında kullanıcılara farklı ve yeşil ile içiçe dinlenme mekanları oluşturulmaktadır.Bu durum estetik değerlerin yükselmesine iş veriminin artmasını mümkün kılmaktadır.Bu tip yapılar sahip oldukları estetik katkıdan dolayı daha değerli yapılardır.

"Doğal yaşam çeşitliliği, bitki örtüsünün renkliliği, hareket ve kokuların ölçülebilir olmamasına rağmen insan sağlığına önemli ölçüde katkı sağladığı bilinmektedir. Ağaçlar ve bitkiler insan üzerindeki stresin azalmasına yardımcı olmakla beraber, kan basıncında düşme, kaslarda gevşemeye neden olarak rahatlama sağlamaktadırlar. Yeşil çatılar bu nedenle insanların psikolojik sağlığında pozitif etki yapabilecektir”(Erkul,2012)

Kentsel yap1 ve nüfus yoğunluğunun artışı rekreasyon alanı ihtiyacınında aynı oranda artması anlamına gelmektedir." Yeşil çatılar; kent ve çevresine rekreasyon alanları sağlamada önemli bir rol üstlenmektedir. Özellikle yoğunluğun fazla olduğu ve yeşil alanların sınırlı olduğu bölgelerde bu rol oldukça fazla görülmektedir.

Barbekü, yemek yeme, güneşlenme, egzersiz, golf gibi birçok aktivite rekreasyon alanlarındaki yeşil alanlarda gerçekleşmektedir”.(şekil 3.12) “İçinde bulunulan ortamın bu fonksiyonlara göre düzenlemesi yapılabilir. Çatıda ise yeşil bir alana sahip olunmasının avantajı, binanın yüksekliği ve çevresine bağlıdır. Bina eğer yüksek ise zemin düzleminde yer alan yeşil alandan daha fazla güneş ışığına maruz kalabilmektedir.

Yoğun bir kent yapılaşmasının içinde ve etrafında yüksek binalar varsa bu binalar tarafından gölgelendirilir" (Learned, 2007).

Ayrıca 1984 Pensilvanya'da yapılan bir sağlık araştırması göstermiştir ki ameliyat sonrası hastaların iyileşme sürecinde doğal manzaraya sahip bir grup hasta sıradan bir oda manzarasına sahip diğer hasta grubuna nazaran daha hızlı iyileşme göstermiştir.

Aynı zamanda yeşil düzenlemeye sahip manzaralı hastaların bulundukları durumdan şikayet etme oranları da diğer hasta grubuna nazaran çok daha az olmuştur.

"Araştırmalar göstermiştir ki, hastane binaları yeşil çatılar için heyecan verici bir potansiyel sunmaktadır. Ayrıca hastanın doğal alan görüşü üzerine daha fazla düşünülmesi ve araştırma yapılmasını gerekli kılmaktadır” (Thomas, 2003). 


\section{Yeşil Çatıların Etkileri}

\subsection{Hava Kirliliği ve Küresel Isınma Nedir ? Oluşumuna Neden Olan Faktörler Nelerdir?}

Hava kirliliği önemli bir çevre problemi olmakla birlikte atmosferde toz,su buharı,gaz,koku yada duman şeklinde bulunabilir ve bu kirletici faktörler çoğunluğu insan kaynaklı nedenlerden dolayı artarak en başta insanlara ve diğer canlı varlıklara zarar verici düzeye ulaşması olarak tanımlayabiliriz.Hava kirliliğinin yapay ve doğal olmak üzere 2 temel sebebi bulunmaktadır.Doğal sebeplerden bahsetmek gerekirse bunlar yanardağ patlamaları ve toz firtınalarıdır.Yanardağ patlamaları sırasında meydana gelen zararlı yanıcı bileşenler havada ki zararları bileşenlerin miktarını arttırmaktadır.Özellikle mevsim geçişleri sırasında meydana gelen toz firtınalarıda hava kirliliğine neden olmaktadır.Yapay nedenler ise tamamen insan faliyetlerine bağlı olarak ulaşım,kentleşme ve sanayileşmede ucuz fakat zararlı enerji kaynaklarının tercih edilmesinden dolayı meydana gelen hava kirliliğidir.Yapay sebeplerin başlangıcı olarak endüstri devrimini yani yaklaşık olarak 150 y1l öncesi gösterebiliriz.İnsan faliyetleri sonucunda atmosfere salınan gazların küresel 1sınmaya etkisi \%13 tarım,\%14 ormansızlaşma, \%24 endüstiriyelleşme ve \%49 enerji kullanımı şeklindedir.Sanayileşmede yanlış lokasyon seçilmesi gerekli filtrasyon sistemlerinin kullanılmaması kentleşmede ise 1sınma ve aydınlatma için gerekli olan enerji ihtiyacının kömür,petrol vb tamamıyla geridönüşümsüz ve sürdürülebilir olmayan enerji kaynaklarının tercih edilmesi,ulaşımda ise içten yanmalı motorların kullanılması hava kirliliğinin başlıca sebeplerindendir.Özellikle plansız ve rant odaklı büyüyen kentler betonlaşmanın artmasına neden olmaktadır.Bir şehrin sahip olduğu yeşil alanlar o şehrin filtre sistemi gibidir.Fakat yeşil alanların plansız kentleşmenin bir sonucu olarak azalmasıyla hava kirliliğide hızlı bir şekilde artmaktadır.

Atmosfer endüstri devriminin getirdiği sanayileşme ve nüfus artışı ile birlikte normal değerlerinin üzerinde zararlı gazlara maruz kalmıştır.Bu zararlı gazlar troposferde yani atmosferin yeryüzüne yakın tabakasında sıcaklığın giderek artmasına sebep olmaktadır.

Örneğin tarım alanlarında salınan $\mathrm{N} 2 \mathrm{O}$ (azot protoksit)gazı CO2'ye göre 300 kat daha zararlı bir gazdır her ne kadar küresel ısınma ve hava kirliliği ile mücadale konusunda yeşil alanların arttırılması bir çözüm olarak görülüyor olsa da yanlış tarımsal faaliyetler sonucu alınacak faydadan daha çok zarar verebilmekte mümkün hale gelmektedir.Küresel 1sınma yalnızca hissedilen sıcaklıkların artmasıyla sonuçlanan bir olay değildir.Yükselen sıcaklıkla beraber gelen çölleşme,su problemleri,sel felaketleri,iklim değişiklikleri gibi felaketlerin yaşanmasıdır.Küresel ısınma aynı zamanda kutuplarda ki buzların erimesine neden olduğu için deniz ve okyanus sularının yükselmesine ve deniz seviyesine yakın yerleşim bölgelerinin sular altında kalmasıyla sonuçlanacak bir felakete neden olacaktır. (Tabak, 2006)

\subsection{Hava Kirliliğinin ve Küresel Isınmanın Neden Olduğu Çevresel Problemler}

Özellikle hava kirliliğine ve dolaylı olarak küresel ısınmaya neden olan çeşitli insan faaliyetlerinden ötürü özellikle endüstri devriminden bu yana büyük çaplı çevresel felaketler yaşanmıştır.2003 yılı Avrupasında hissedilen sıcaklıkların sağlığı tehdit edecek boyutlara ulaşmasından ötürü 40bin civarı insan ölümü gerçekleşmiştir. Tabi ki küresel 1sınma ve hava kirliliğinin onlarca neticesinden yanlızca biri bile ölümlü felaketlerin yaşanmasına neden 
olabilmektedir.

$\mathrm{Bu}$ nedenle doğal ve yapay havalandırma sistemlerinin kurulması,özellikle yaşlı ve hasta insanlara yönelik planlamaların yapılması elzemdir.Değişen iklim şartlarının beraberinde getirdiği aşırı hava olayları sel baskınlarına, kuraklıklara, fırtınalara, kasırgalara ve orman yangını gibi olaylara neden olmaktadır.Tabiki yaşanan her felaket hava kirliliğinin artmasına ve dolaylı olarak küresel ısınmanın hızlanmasına neden olmaktadır.Hava kirliliğinin beraberinde getirdiği sağlık problemleri de bir diğer önlem alınması gereken konunun başında yer almaktadır.

Son yüzyıl dikkate alındığında hava kirliliği sonucu yaşanan sağlık problemlerinde ciddi artışlar olduğunu gözlemlemekteyiz.Hava kirliliğinin artması sonucu özellikle solunum sistemi hastalıkları,kardiyovasküler sistem bozuklukları,sinir sistemi hastalıkları,ürinir ve sindirim sistemi hastalıkları meydana gelmektedir. İklim değişikliğinin neticeleri gelişmemiş ve gelişmekte olan ülkelerde daha fazla hissedilecektir.Nüfus yoğunluğunun fazla olması,ekonomik imkan ve düzeyin düşük olması,besin tedariğinde güçlükler yaşanması,gelir dağılımında ki eşitsizlikler,mevcut olan sağlığı koruma bilincinin düşük olması ortaya çıkacak olan neticelerin artmasına neden olacaktır.

Hava kirliliğinin neden olduğu çevresel felaketlere en büyük örneklerden biri Londra'da 1952 yılında yaşanan sis felaketidir.Isınma ve enerji üretiminde kullanılan düşük maliyetli,geridönüşümsüz kaynaklar,ulaşımda insan sağlığı için son derece zararlı olan kurşun içeren yakıtın kullanılması,elektrikli toplu ulaşım araçlarının kaldırılıp mazot ile çalışan araçların kullanımı bu felaketin yaşanmasına neden olmuş ve üst solunum yolu rahatsızlığı gibi benzer rahatsızlıklardan dolayı 1 hafta içinde 5 bin 1 sene içerisinde 12bin insanın ölümüne yol açmıştır.Olaydan dolayı hastalananların sayısı ise 100bini bulmuştur.

Asit yağmurların toprakla buluşmasının ardından öncelikli olarak toprağın zirai verimi azalır aynı zamanda yağmur ile birlikte toprağa inen zararlı maddeler toprağın yapısını asitik hale getirir bu maddeler aynı zamanda toprakta çözünemediği için besin zinciri yada içme suyu yoluyla bu topraktan beslenen diğer canlıların vücuduna geçmektedirler.Özellikle 4.6ph'dan daha asidik yağmur suları deniz canlılarının yaşamını tehdit etmektedir.Besin zincirinin en üstünde yer alan insanlar için ise asit yağmurlarına mahrum kalan mahsullerin tüketilmesi deri hastalıklarından,guatra,ülser ve kronik bronşite kadar bir çok hastalığa neden olabilmektedir. (Kızıloğlu ve Bilen, 2000).Küresel 1sınma bugün günümüz ekosistemini tehdit etmekle birlikte aynı tedbirsizlik ortamı devam ettiği sürece gelecek ony1llarda etkisini ve tehditini arttıracaktır.Önümüzdeki yüzyılda gezegenimiz $1,40-5,80$ aras1 1sınmas1 beklenmektedir.Küresel ısınmanın etkisinin artmasıyla bugün yaşadığımız problemleri çok daha aşırı şekilde görebileceğiz.

\subsection{Yeşil Çatıların Hava Kirliliği ve Küresel Isınma İle Mücadelede ki Etkileri ve Önemi}

Elbette yapıları yeşil çatı ile kaplamak hava kirliliği ve küresel ısınmanın yaratacağı tüm neticeleri engellemesi beklenemez.Küresel ısınma ve hava kirliliği ile alakalı olarak alınacak önlemler öncelikli olarak nüfus yoğunluğu fazla olan kentlerden başlaması elzemdir.Bunun nedeni ise sera etkisine neden olan CO2 emisyonunun \%80'lik kısmı kentlerin enerji,ulaşım ve 
diğer tüm faliyetlerinden kaynaklanmaktadır.Dünya üzerindeki nüfusun 7 milyara yakın olduğu tahmin edilmekte ve bu nüfusun yarıya yakın bir kısmı küçük ve büyük ölçekli kentlerde yaşamaktadır.Nüfus artışı yeşil alanları yok ederek yerini geçirimsiz sert zemine bırakmaktadır.Değişen iklim koşullarıyla birlikte yaşanan aşırı iklim olayları kent yaşam konforunu etkilemektedir.Kentsel alanlarda ki ısı farkl1lıkları hissedilebilir düzeydedir.

Geleneksel çatı malzemelerinin yüzeyi yaz aylarında özellikle aşırı 1sınır ve 1sının büyük bir kısmı yapının alt katlarına iletilir.Sert zeminler ve yüzeyler gün içerisinde 1sıyı hapseder ve gece 1sıyı dağıtırlar bu durum kentin çevresinde bir ısı adası oluşmasına neden olur.

Yapılan araştırmaya göre Toronto kentinde ki çatıların yarısının yeşil çatı sistemi ile kaplanması kent merkezinde hissedilir sıcaklığı 2-3oC düşürebileceği tespit edilmiştir.Yeşil çatıların buharlaşma ve yansıtıcılık özelliği hissedilir sıcaklığın düşürülmesinde önemli bir rol oynar.

Yanlızca otomobiller dünyadaki küresel ısınmanın \%21'den sorumludur.1850-1900 y1llar aras1 egzoz kaynaklı kurşun salımları 20bin ton seviyelerindeyken 1980'lerin sonuna geldiğimizde bu oran 430bin tona kadar çıkmıştır.Ardından gelişen teknoloji sayesinde 2000lerin başında 300bin tona kadar gerilemiş̧ir.Günümüzde artan emisyon standartları neticesinde hibrid otomobiller ve hatta elektrikli otomobillere geçiş başlamıştır.Fakat hiçbir önlem yada gelişme doğal olan önlemlerin yerini alamayacaktır.

Ortalama büyüklükte bir ağaç günde 450litre suyu nem olarak dişarıya salmaktadır.Bu buharlaşma ortalama 900bin KJ enerjiye eşittir.Bu buharlaşmanın sağladığ1 soğutmayı elde edebilmek için 10bin KJ'lik 5 adet klimanın 19 saat boyunca çalışmasına denk olduğunu görmekteyiz.Fakat yapay havalandırma sistemleri yenilenebilir olmayan enerji kaynaklarını kullanır fakat ağacın suyu neme çevirmesi olayı ise ekolojik sisteme ek bir yük getirmeyeceğinden dolayı çok daha sürdürülebilir bir soğutma sağlamaktadır.Tüm bu kazanımın yanlızca bir yapının çatısında değilde tüm kent boyutunda düşünüldügünde sağlanılan enerji tasarrufu ülkenin enerji sarfiyatında ciddi bir tasarruf kalemi olabileceğini göstermektedir.(Yeang,2006)Aşağıdaki görsellerde yapılaşmanın olduğu alanlar ve yeşil alanlar resmedilmişdir.Görsellerden anlaşılacağı üzere yeşil alanlardan mahrum kalan alanlarda kentsel 1sı adaları oluşmuştur

\section{SONUÇ ve DEĞERLENDIRME}

Esas olarak çevremizdeki yapaylık ve inorganiklik durumu gün geçtikçe artmaktadır.Bu konuda ele alınan nokta ekotasarımcıların bu durumu dengelemeye çalışması gerektiğidir.İnorganik ve organik içeriği dengelemeye çalışmak bozulmuş olan yaşam çevremizin rehabilitasyonu için son derece önemlidir.Yeşil alanların toplam dünya toprak kütlesine oranı her ne kadar \%40 dolaylarında olsada bu miktar hızla azaldığından ötürü alınabilecek her türlü tedbir büyük önem arz etmektedir.Öyle ki daha yaşanılabilir olması adına tüm yapay çevre doğanın bir parçası gibi görünmelidir.Bitkiler bulundukları çevreye fotonsentez yoluyla oksijen üretir,karbondioksiti emer,suyun akışını denetler,suyu süzer,ekosistem için besin üretir,havayı filtre ederek hava kalitesini yükseltir.Dengeli bir yapay çevre oluşturmak adına tüm işlevleri çevremize kazandırmamız gerekmektedir.Bu doğrultuda yeşil çatı sistemleri inorganik ve organik dengenin sağlanmasında kullanılabilir en akılcı sistemlerin başında gelmektedir.Yoğun trafiğin ve hava kirliliğinin olduğu kalabalık semtlerde büyük metrekarelere sahip yapıların çatısını yeşil 
alanlar olarak değerlendirmek yanlızca 1sı adası etkisini azaltmayacak aynı zamanda küresel 1sınmanın etkilerini de azaltmaya yardımcı olacaktır.

Olayın özüne inildiğinde zaman neticelerini felaketler ile yaşadığımız küresel ısınma ve hava kirliliği için alınabilecek en büyük tedbiri denge olarak özetleyebilir 10m yüksekliğinde ve $6 \mathrm{~m}$ tac genişliğine sahip bir ağacın yılda $160 \mathrm{~kg}$ karbondioksiti emebildiği tahmin edilmektedir.Her ne kadar aynı etkiyi sağlayacak bir ağaç popülasyonu ve yeşil çatının maliyeti karşılaştırılamayacak kadar yeşil çatının aleyhine olsada ağaçlar büyüme,gelişim süresince havadaki karbondioksiti emerler.Ağaçların büyüme hızları yavaşladıkça karbondioksiti emme hızlarıda yavaşlayacaktır.

Ağaçlar öldüklerinde ise karbonlarını karbondioksit olarak atmosfere bırakırlar bu durumda ağaçlardan sağlanılan yararın sürdürülebilir olması ve sonsuza kadar sürmesi adına yeşil çatı sistemlerinin kullanılması önemlidir.Çünkü yeşil çatıda kullanılan tüm bitkiler sürekli kontrol altında olacağından en verimli halde bir yeşil alan alan popülasyonu sağlamak mümkün olacaktır.

Ülkemiz de elbette bir tedbir olarak kişi başına düşen yeşil alan miktarı 3194 sayılı İmar kanunu ile belirlenmiştir.Yapılan en son değişikliklikler ile birlikte kişi başı alan $10 \mathrm{~m}^{2} /$ kişi olarak belirtilmiştir.Bu oran gelişmiş ülke statüsündeki ülkerin çok gerisinde kalmasına rağmen ne yazık ki metropollerimizde bu oranı bile yakalamak mümkün değildir.

Örneğin Amerika için belirlenen oran 250/ha yine İngiltere'de $40 \mathrm{~m}^{2}$ standart1 benimsenmiştir.Almanya Stutgart'ta $153 \mathrm{~m}^{2} /$ kişi,İsveç Stockholm'de $107 \mathrm{~m}^{2}$,Amerika

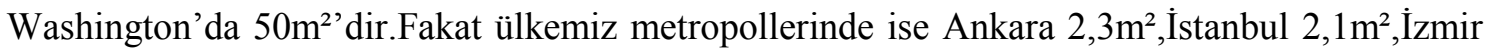
de ise $2,8 \mathrm{~m}^{2}$ dir.Bu oranlar göz önüne alındığında şehrin yeşil alanlarının çoğunu kaybettiği görülmektedir.Betona dönen yeşil alanların tekrar yeşil alanlara dönüşme ihtimali çok düşük olduğundan belirli $\mathrm{m}^{2}$ üzerinde kapalı alana sahip konut projelerine yeşil çatı zorunluluğu getirilmesi bir tedbir olarak alınabilir.(Onsekiz,2019)

Sonuç olarak aslında yeşil çatılar biliçsiz,plansız ve yarınları düşünmeden yapılan tüketimlerin,harcamaların neden olduğu problemleri çözmenin onlarca yolundan yanlızca birtanesi olarak düşünülebilir.Yeşil çatı uygulamaları yanlızca yarınları kurtarabilmek için bugünden almamız gereken tedbirlerden biri olarak karşımıza çıkmaktadır.Konuda gösterilen veriler 1şığında hergeçen gün keşkemekeş durumun giderek daha da arttığı şehirlerde biraz olsun doğal havayı teneffüs edebilmek için yeşil çatılara nedenli muhtaç olduğumuz ortaya koyulmaya çalışılmıştır.Dünya üzerinde ki örnek yapılarda bu tedbirin aslında uygulanabilir bir sistem olduğunu ortaya koymaktadır. 


\section{KAYNAKLAR}

Arslan F., (2014), “Türkiye'de Sürdürülebilir Doğal Kaynak Kullanımı Arayışlarına Bir Örnek: Yeşil Binalar", Akademik Sosyal Araştırmalar Dergisi, 2(1), 288-304.

Çepel, N., 2003: Ekolojik Sorunlar ve Çözümleri, Tübitak Popüler Bilim Kitaplar.

Ekşi M., Rowe D. B., (2014), "Bitkilendirilmiş Çatı Sistemleri ve Kentsel Tarım Olanakları”, 7. Ulusal Çatı \& Cephe Sempozyumu, Yıldız Teknik Üniversitesi, Beşiktaş, İstanbul, Türkiye, 3-4 Nisan.

Erkul E.,2012, Yeşil Çatı Sistemlerinin Yapım Açısından İrdelenmesi,Dokuz Eylül Üniversitesi Gault M.,2009,Acros Fukuoka’s Step GARDEN.

Hake, A. (2007). Promoting Sustainable Green Roofs Through Leadership in Energy and Environmental Design (LEED). Manhattan, Kansas: Kansas State University, Department of Landscape Architecture, Regional and Community Planning, College of Architecture, Planning and Design, The Degree of Master of Landscape Architecture.

Hemstuck, B. (2010). Living Roof Case Study; Vancouver Convention Centre. SAB Mag (Sustainable Architecture \& Building Magazine), 15 Ağustos 2011, http://www.sabmagazine.com/blog/2010/03/11/21-living-roof-case-study/.

Karaosman S.K., (2002), “Yeşil Çatıların Ekolojik Yönden Değerlendirilmesi”, Ulusal Çatı ve Cephe Kaplamalarında Çağdaş Malzeme ve Teknolojiler Sempozyumu

Koca A.,(2017),Yeşil Çatı Sistemlerinin Sürdürülebilir Kent Yaşamına Etkilerinin Değerlendirilmesi,Yüksek Lisans Tezi,Gebze Teknik Üniversitesi

Koç Y.,Gültekin A. B.,2010,Yeşil Çatılar ve Türkiyedeki Uygulamaları,Ulusal Çatı ve Cephe Sempozyumu,İzmir

Klein C.,(2018)"The Great Smog of 1952",1 Haziran 2019”, www.history.com/news/the-killerfog-that-blanketed-london-60-years-ago.

Özmen T.,(2019),"Sera Gazı - Küresel Isınma ve Kyoto Protokolü”,1 Haziran 2019, www.imo.org.tr/resimler/ekutuphane/pdf/16154_50_07.pdf.

Rowe D.B.,2010,Green Roofs as a Means Of Pollutant Abatement”,Env.Pollution .

Snodgrass E.C.,2006,Green Roof Plants,A Resource and Planting Guide

Söğüt Z.,(2014) ,’Kentsel Çevre Kapsamında Yeşil Çatı ve Cephelerin Değerlendirilmesi”,Çukurova Üni,Ziraat Fakültesi,Peyzaj Mimarlığı Bölümü

Tabak P.,(2006),Küresel Isınma Nedeniyle Suların Yükselmesi Problemine Karşı Konut Mimarisinde Çözüm Önerilerinin Araştııılması,Yıldız Teknik Üniversitesi

Tokaç, Tufan, 2009: Bitkilendirilmis Çatı Sistemlerinde Tasarım Seçeneklerinin

Gelistirilmesi, Yayınlanmamıs Yüksek Lisans Tezi, İTÜ Fen Bilimleri

Enstitüsü, İstanbul.

Tosun Karakurt, E., 2009: Sürdürülebilirlik Olgusu ve Kentsel Yapıya Etkileri: 
Paradoks, Ekonomi, Sosyoloji ve Politika Dergisi, (e-dergi),

http://www.paradoks.org, ISSN 1305-7979, Y11:5 Say1:2

Uçurum E.,2007,Sürdürülebilirlikte Ekolojik Çatının İncelenmesi

Uzun A.,(2015),“Yeşil çatı sistemlerinin su ve enerji dengesi açısından değerlendirilmesi”,IÜ Orman Fakültesi Dergisi

Worden E.,2004, “Green Roofs in Urban Landscapes”, Env. Horticulture Department

Yeang K.,(2006),"Ecodesign”,148-161. 